\title{
Eksistensi Pelaku Usaha Sektor Informal Offline dan Online di Tengah Pandemi Covid-19
}

\author{
Mirna Taufik* \& Armansyah \\ Program Studi Pendidikan Geografi, Fakultas Keguruan dan Ilmu Pendidikan \\ Universitas PGRI Palembang, Indonesia
}

Disetujui: Maret 2021; Direview: April 2021;Diterima: Mei 2021

\begin{abstract}
Abstrak
Penelitian ini bertujuan untuk eksistensi pelaku usaha sektor informal offline dan online di tengan pandemi covid 19. Metode yang digunakan dalam penelitian ini adalah metode kualitatif dengan pengumpulan data menggunakan observasi dan wawancara. Analisis data yang digunakan yaitu data reduction, data display dan penarikan kesimpulan. Hasil penelitian yang diperoleh Sektor informal online merupakan jalan yang harus ditempuh, untuk tetap melaksanakan usaha dan memenuhi kebutuhan keluarga, sehingga dapat dikatakan sektor informal di masa pandemi covid-19 lebih eksis dibandingkan dengan sektor informal offline. Penjualan secara offline tetap dilakukan sebagian masyarakat karena adanya keterbatasan dalam penggunaan teknologi, selain itu banyak masyarakat melakukan penjualan secara online dan tidak offline, akan tetapi tidak jarang masyarakat juga melakukan usaha secara offline dan online. Sistem penjuan offline dan online yang dilakukan secara bersamaan agar kegiatan masyarakat sektor informal tetap berjalan sebagai mana mestinya. Mau tidak mau, suka atau tidak suka masyarakat harus mampu menjalankan usaha secara offline dan online ditengan pandemi dan juga kemajuan teknologi.
\end{abstract}

Kata Kunci: Pelaku Usaha, Sektor Informal, Covid-19

\begin{abstract}
This study aims for the existence of offline and online informal sector business actors in the midst of the covid 19 pandemic. The method used in this study is a qualitative method with data collection using observation and interviews. Analysis of the data used is data reduction, data display and drawing conclusions. The results of the research obtained that the online informal sector is the path that must be taken, to continue to carry out business and meet family needs, so it can be said that the informal sector during the COVID-19 pandemic is more existent than the offline informal sector. Offline sales are still carried out by some people because of limitations in the use of technology, besides that many people sell online and not offline, but it is not uncommon for people to also do business offline and online. An offline and online sales system that is carried out simultaneously so that the activities of the informal sector community continue to run as they should. Like it or not, like it or not, people must be able to run businesses offline and online in the midst of a pandemic and also technological advances
\end{abstract}

Keywords: business actors, informal sector, Covid-19

How to Cite: Taufik, Mirna dan Armansyah. (2021). Eksistensi Pelaku Usaha Sektor Informal Offline dan Online di Tengah Pandemi Covid-19. PUBLIKAUMA: Jurnal Ilmu Administrasi Publik UMA, 9 (1): 57-66

${ }^{*}$ Corresponding author:

ISSN 2549-9165 (Print)

E-mail:mirna12@yahoo.com

ISSN 2580-2011 (Online) 


\section{PENDAHULUAN}

Pandemi covid-19 melanda seluruh negara-negara yang ada di dunia tidak terkecuali Indonesia. Adanya penyebaran pandemi covid-19 secara cepat menyebabkan negara-negara mengambil tindakan untuk memberlakukan lockdown dan social distancing, sebagai usaha pencegahan terjadinya penyebaran virus covid-19. Tidak ketinggalan Indonesia sebagai negara dengan jumlah penduduk yang tinggi, juga mengambil keputusan untuk memutus mata rantai penyebaran pandemi covid-19 dengan memberlakukan PSBB atau pembatasan sosial berskala besar. Pemberlakuan PSBB dinilai dapat memutus penyebaran pandemi covid19, akan tetapi juga menimbulkan dampak besar bagi semua negara dan juga masyarakat.

Covid-19 pertama kali teridentifikasi di Wuhan, China pada Desember 2019 (Moriarty et al., 2020). Virus ini masih sejenis dengan virus SARS dan MERS (Vellingiri et al., 2020) namun yang membedakannya Covid-19 memiliki daya sebar yang sangat cepat (Lupia et al., 2020), jika ada satu orang yang terkena maka dengan sangat cepat dapat menularkan pada orang lain, apalagi jika terjadi pada tempat atau ruangan tertutup seperti yang terjadi pada kasus kapal pesiar Diamond Princess. Oleh karena itu, salah satu cara pencegahan yakni dengan melakukan investigasi atau penyelidikan dan isolasi pada tempat-tempat atau daerah di mana terdapat penderita Covid-19 (Kakimoto et al., 2020).

Pemberlakuan PSBB menyebabkan berkurangnya jam kerja pada seluruh badan usaha, perusahaan serta aparatur sipil negara dan juga adanya larangan untuk berkerumun. Hal tersebut tentunya berpengaruh besar pada semua sektor terutama sektor informal. Pada Agustus 2019, tercatat 55,72 persen atau sejumlah 70 juta orang tenaga kerja Indonesia berada di sektor informal (BPS, 2019). Jumlah jam kerja mereka, sebagian besar lebih dari 48 jam per minggu. Itu artinya telah melebihi jumlah jam kerja normal yang ditetapkan oleh BPS, yaitu 35-48 jam per minggu. Jumlah jam kerja yang berlebih ini akan mempengaruhi tingkat produktivitas, kesehatan, dan keamanan pekerja. Namun bagi pekerja sektor informal waktu kerja berlebih hampir tidak dapat dihindari, sebab berhubungan dengan pendapatan yang akan dihasilkan.
Sektor informal sering disebut sebagai 'katub pengaman' bagi masyarakat menengah ke bawah (Pitoyo, 2007). Hal ini disebabkan sifat sektor informal yang fleksibel atau mudah dimasuki oleh siapa saja dengan karakteristik apapun (Soebyakto \& Armansyah, 2016; Wulantari \& Armansyah, 2018). Selain itu sektor informal juga bersifat adaftif (Pitoyo, 1999) pada segala situasi dan kondisi. Hal ini terlihat pada masa krisis 1998, di mana banyak pekerja yang terkena PHK beralih melakukan pekerjaan sektor informal untuk bertahan hidup. Selain sebagai katup pengaman, sektor informal juga merupakan strategi bertahan hidup populer bagi masyarakat menengah ke bawah (Williams \& Nadin, 2012; Armansyah, et al., 2019). Saat dilanda kemiskinan, situasi ekonomi, politik dan keamanan tidak stabil, maka sektor informal merupakan pilihan yang rasional bagi masyarakat untuk bertahan hidup dan memperoleh pendapatan.

Kajian tentang sektor informal mulai banyak dilakukan pada periode 1970-1980, diantaranya dilakukan oleh Hart (1973), (Werlin, 1974), Norwood (1975), Chana \& Morrison (1975), dan Sinclair (1976). Para peneliti tersebut melakukan kajian tentang sektor informal seperti pedagang kaki lima atau pedagang jalanan di beberapa wilayah negara berkembang seperti pada kota-kota Asia Tenggara dan Amerika Latin. Fenomena informalitas merupakan ciri-ciri daerah perkotaan yang menonjol di perkotaan dan sering dipandang sebagai kegiatan yang bertentangan dengan modernisi sehingga sering termarginalkan (Rogerson, 2017).

Istilah sektor informal pertama kali muncul pada tulisan Hart (1973) yang berjudul "Informal Income Opportunities and Urban Employment in Ghana".Istilah sektor informal disematkan untuk jenis pekerjaan tidak terdaftar dan di luar regulasi pemerintah yang banyak dilakukan oleh para pendatang (migran) dari Frafra, di perkotaan Accra, Ghana dengan penghasilan rendah, tidak terampil, dan buta huruf (Hart, 1973), terhindar dari pajak, dan tidak mendapat jaminan sosial dari pemerintah (Timofeyev, 2012). Informalitas terjadi disebabkan oleh inflasi harga, upah rendah, dan rigitnya persyaratan untuk masuk ke pekerjaan di perkotaan. Istilah sektor informal juga sering digunakan untuk menunjukkan jenis pekerjaan 
yang tersembunyi, bawah tanah, hitam atau 'hidden', underground', 'black' economy' (Hart, 1985). Oleh karena itu, pekerja sektor informal memiliki tingkat ketidakamanan tinggi, dan tidak memiliki kontrak kerja yang jelas (Timofeyev, 2012).

Pada kondisi saat ini pandemi covid-19 melanda seluruh negara termasuk Indonesia, salah satunya kota Palembang. Pemberlakuan PSBB mengakibatkan keadaan ekonomi masyarakat semakin tidak stabil, para pekerja sektor informal seperti buruh, pedagang, tukang ojek, tukang tambal ban dan pekerja sektor informal lainnya. Perusahaanperusahaan mengalami kerugian dan penurunan pendapatan sehingga terpaksa melakukan PHK pada sebagian pekerjanya.

Kondisi ini pastinya akan berdampak serius pada kehidupan ekonomi keluarga khususnya para pekerja sektor informal yang tidak memiliki gaji bulanan atau penghasilan tetap. Jika kondisi ini terus berlangsung secara terus menerus tentu akan memperburuk prekonomian masyarakat terutama sektor informal jika tidak di imbangin dengan kemampuan-kemampuan dalam mengembangkan inovasi baru melalui teknologi. Seperti sektor informal yang ada di kota Palembang tetap menjalankan usahannya meski dikondisi pandemi saat ini, karena tidak adanya pilihan lain agar tetep bertahan. Bahkan masyarakat yang kehilangan pekerjaan terpaksa memasuki sektor informal untuk memenuhi kebutuhan keluarga dengan cara menjalankan sektor informal secara online.

Era modernisasi seperti saat ini, masyarakat kota Palembang tidak tinggal diam dengan keadaan yang sedang dihadapi. Sebagian besar masyarakat melakukan usaha sektor informal secara online agar tetap dapat menjalankan usaha yang selama ini ditekuni. Bahkan pekerja sektor informal harus bersain karena, kemampuan dalam menggunakan teknologi menentukan hasil yang akan didapat. Terlebih pada saat berlakunya PSBB yang mengharuskan masyarakat tidak kluar rumah. Sehingga saat munculnya covid 19 sampai saat ini sudah menjadi suatu hal yang biasa jika ditemui pekerja sektor informal offline dan online, sehingga penelitian ini bertujuan untuk mengetahui eksistensi pekerja sektor informal offline dan online di masa pandemi covid-19.

\section{METODE PENELITIAN}

Penelitian ini menggunakan metode kualitatif sebab untuk menjawab bagaimana dampak dan eksistansi pelaku usaha sektor informal di tengah wabah Covid-19 memerlukan pengumpulan data dengan teknik indepth interview. Metode kualitatif adalah teknik penelitian yang berusaha mendapatkan data dengan pendekatan natarulistik, apa adanya, rinci dan mendalam. Bentuk informasi dan data yang dikumpulkan berupa kata-kata atau narasi dan informan penelitian (Sugiyono, 2016). Teknik sampling yang digunakan pada penelitian adalah purposive sampling dengan beberapa kriteria sebagai berikut: 1) Merupakan pelaku usaha sektor informal offline atau online; 2) Masa kerja lebih dari 1 tahun; 3) Berdomisili di Kota Palembang.

Pengumpulan data pada penelitian ini dilakukan dengan dua acara, yaitu wawancara mendalam (indepth interview) dan dokumentasi. Wawancara mendalam mengikuti pedoman wawancara yang telah disusun namun dapat berkembang apabila diperlukan. Pedoman wawancara hanya sebagai pemandu agar proses wawancara dapat berjalan baik, peneliti sebagai instrumen dapat menambahkan pertanyaan apabila dalam proses wawancara ditemukan informasi yang dinilai penting untuk terus digali. Analisis data yang digunakan dalam penelitian ini adalah Model Miles dan Huberman, yaitu, reduction, display, dan conlusion (Creswell, 2016).

\section{HASIL DAN PEMBAHASAN}

Teknologi selalu mengalami perkembangan yang sangat pesat, mengharuskan semua kalangan harus mampu beradaptasi terhadap kemajuan teknologi terutama teknologi komunikasi. Hampir di setiap kalangan seperti anak-anak, remaja, dewasa, orang tua, pegawai, pengusaha dan bahkan pengangguran juga memiliki media komunikasi jarak jauh. Perkembangan teknologi tidak hanya sebatas alat komunikasi yang digunakan sebagai alat komunikasi. Kemajuan teknologi disertai dengan keterampilan masyarakat menggunakannya sehingga dapat digunakan sebagai media dalam menjalankan usaha teruma kondisi pandemi Covid-19 saat ini. Segala kegiatan interaksi dilakukan dengan cara daring seperti sekolah, rapat, seminar dan bahkan berbelanja 
juga sering dilakukan secara daring. Pelaku usaha, terutama sektor informal di kondisi pandemi covid-19 seperti saat ini, harus mampu menggunakan berbagai media dalam menjalankan usaha. Tidak sedikit pelaku usaha sektor informal menjalankan usahanya secara online, sehingga muncul istilah pelaku usaha sektor informal offline dan online. Meskipun sama-sama pelaku usaha informal tentu ada beberapa perbedaan yang dirasakan penjual dan juga pembeli, sehingga dari hasil wawancara dapat dilihat eksistensi dari pelaku usaha informal offline dan online hal ini dapat dilihat dari daya pembeli, pendapatan, kemampuan menabung di masa pandemi. Ketiga kategori tersebut akan diuraikan dalam pembahasan di bawah ini.

\section{Daya Beli Pada Usaha Sektor Informal Offline Dan Online}

Pandemi covid-19 saat ini melanda seluruh negara termasuk Indonesia yang tentunya mau tidak mau akan berdampak pada seluruh sektor, baik sektor formal maupun sektor informal. Keberadaan sektor informal sudah menjadi salah satu ciri khas dari negara kita, menjamurnya sektor informal seperti pedagang, jasa dan petani menjadi salah satu tulang punggu penggerak kegiatan ekonomi selama ini. Sektor informal dinilai sangat efisien dalam penggerak ekonomi terutama prekonomian keluarga dari masyarakat kecil. Keberadaan pandemi covid19 memberikan dampak yang besar bagi semua prekonomian masyarakat terutama masyarakat yang bergerak di sektor informal.

Dampak yang muncul terjadi karena adanya pembatasan terhadap pergerakan orang atau barang dari berbagai tempat, daerah atau wilayah guna pencegahan penyebaran covid-19. Hal ini tentunya akan berdampak juga pada penurunan interaksi antara penjual dan pembeli secara langsung yang menyebabkan menurunnya kegiatan ekonomi, yang berakibat pada penurunan prekonomian masyarakat. Penurunan prekonomian masyarakat dapat dilihat dari penurunan konsumsi dan daya beli masyarakat yang tentunya banyak masyarakat yang akan mengalami kemerosotan dalam ekonomi terutama pekerja sektor informal harian.

Usaha sektor informal merupakan usaha yang sangat fleksibel yang bisa dilakukan masyarakat karena dapat dilakukan oleh siapa saja, mulai dari anak-anak, remaja, dewasa, orang tua, dari pendidikan rendah sampai berpendidikan tinggi, tidak memiliki skill sampai yang memiliki skill. Akan tetapi menurut (Mussurov \& Absheibani, 2015), usaha sektor informal lebih diminati oleh usia yang relatif tua terutama di kondisi krisis, begitupun dengan masyarakat yang telah berkeluarga dan memiliki anak lebih memilih bekerja di sektor informal (Soebyakto \& Armansyah, 2016; Armansyah \& Mirna, 2018; Taufik, dkk., 2019; Armansyah \& Taufik, 2020). Kondisi pandemi covid-19 seperti saat ini, sangat penting adanya kemampuan masyarakat dalam menciptakan inovasi baru dalam menjalankan usaha di sektor informal. Salah satu inovasi yang dapat dilakukan masyarakat pada pandemi saat ini yaitu beralih dari offline menjadi online, dan bahkan tidak jarang masyarakat menjalankan usaha secara offline dan online akan tetapi ada juga masyarakat tetap bertahan dengan cara offline, seperti hasil wawancara yang dilakukan di lapangan pada pedagang makanan.

"saya jualannya ya tetap di disini saya jualan dari pagi sampai jualan saya habis, saya tidak berjualan secara online karena saya tidak bisa menggunakan $\mathrm{hp}$ yang digeser-geser, pembelinya tidak sebanyak dulu sebelum covid. Daripada drumah saja ya mending saya jualan sedapatnya saja yang penting bisa memenuhi kebutuhan hidup walau tidak sebanyak dulu, tapi ya dicukupcukupkan saja, jangkan untuk menabung untuk makan sehari-hari saja sudah syukur. (I_07-Sr)

Masyarakat sebagai pedagang makanan yang hanya menjalankan usaha secara offline, mengatakan bahwa di kondisi pandemi covid19 saat ini sangat berdampak pada daya beli msayarakat. Daya beli masyarakat sangat jauh menurun dibandingkan sebelum adanya pandemi covid-19, yang tentunya berdampak pada pendapatan pekerja sektor informal, kemampuan menabung dan bahkan kemampuan dalam berinvestasi. Pelanggan yang biasanya berbelanja secara offline atau datang langsung ke lokasi lebih memilih berbelanja secara online. Dibuktikan hasil hasil studi (Armansyah \& Taufik, 2020) pelaku 
usaha informal offline lebih cenderung memilih mengurangi jumlah pekerja akibat menurunnya jumlah pendapatan karena berkurangnya pembeli, sedangkan pelaku usaha informal online lebih cenderung menambah jumlah pekerja, karena terjadi peningkatan pembeli. Pedagang makanan yang dilakukan secara offline mengatakan bahwa.

"Dulu pembeli yang datang ke warung saya sebelum covid cukup ramai dan bisa memenuhi kebutuhan sehari, tapi sekarang sangat sepih pembeli karena pembeli sekarang lebih suka membeli makan melalui hp jadi warung saya sepih. Apalagi saya tidak bisa menggunakan hp untuk berjualan "( I_04-Am)

Sebelum adanya pandemi covid-19 usaha yang ditekuninya selama ini sebagai pedagang makanan secara offline cukup ramai dikunjungi pembeli. Akan tetapi adanya pandemi covid-19, pembeli perlahan-lahan mulai berkurang yang tentunya berdampak pada pendapatan yang akan didapat. Keterbatasan pemahaman dalam penggunaan teknologi mengharuskan pedagang tetap menjalankan usaha secara offline di pademi covid-19. Meski pedagang menyadari daya beli masyarakat lebih tinggi secara online dibandingkan dengan offline, melihat adanya pemberlakuan PSBB dilingkungan masyarakat. Sama seperti pendapat pedagang yang melakukan usaha secara offline dan online.

"Usaha yang dilakukan secara offline sebelum adanya covid-19 cukup ramai pembeli dibandingkan setelah adanya covid, jadi saya melakukan penjualan secara online juga semenjak adanya covid dan pembelinya memang lebih ramai dibandingkan dengan offline" ( I_02-Da)

Kemajuan teknologi disambut baik oleh sebagian besar masyarakat termasuk pedagang, sebelum adanya covid-19 kegiatan penjualan sudah ramai dilakukan secara online. Terlebih pandemi covid-19 saat ini, segala sektor dilakukan secara online baik sektor formal maupun sektor informal. Para pelaku sektor informal seperti pedagang makanan menjalankan usahanya secara offline tidak hanya tinggal diam melihat kondisi usaha yang digelutinya mengalami penurunan pembeli. Pedagang melakukan gebrakan dengan cara berjualan secara offline dan online. Kondisi ini tentu tidak secara otomatis mengembalikan pelanggan atau kondisi pembeli seperti sebelum adanya pandemi covid-19, namun kegiatan berjualan yang dilakukan secara offline dan online cukup membantu prekonomian masyarakat di kondisi pandemi saat ini. Kondisi serupa juga terjadi pada sektor informal lainnya seperti jasa pangkas rambut.

"Semenjak covid-19 orang sangat jarang datang untuk potong rambut, karena pelanggan ditempat saya kebanyakan anak sekolah sedangkan sekarang ini sekolah dilakukan dirumah, jadi mereka tidak potong rambut tiap bulan seperti biasanya, seperti sekolah dilakukan secara langsung" (I_01-Az)

Sudah sejak lama menjalankan usaha pangkas rambut akan tetapi selama pandemi covid-19 mengalami penurunan yang cukup besar. Agar usaha yang dijalankan tetap berjalan, jasa pangkas rambut menggunakan media online untuk memasarkan jasanya. Memberitahu kepada konsumen usaha pangkas rambut yang dijalankan mematuhi protokol kesehatan dan menyediakan tempat cuci tangan dan hal-hal lainnya yang berkaitan dengan protokol kesehatan yang disarankan oleh pemerintah. Pemasaran secara online cukup membatu usaha pangkas rambut meski tidak seramai sebelum adanya pandemi covid19. Biasanya pelanggan yang ramai setiap bulannya adalah pelanggan usia sekolah karena adanya peraturan di sekolah, rambut untuk siswa laki-laki harus pendek, sehingga dengan adanya peraturan pemerintah diberlakukannya sekolah secara daring menyebabkan berkurangnya jumlah pelanggan terutama usia sekolah.

Maka dapat disimpulkan bahwa daya beli masyarakat pada saat pandemi covid 19 mengalami penurunan pada sektor informal offline. Adanya pemberlakuan pembatasan berskala besar mengharuskan masyarakat untuk tidak keluar rumah jika tidak diperlukan. Bahkan semua kegiatan masyarakat di alihke ke rumah seperti aktifitas belajar disekolah dilahkan ke pembelajaran 
daring di rumah, kegiatan kantor menjadi WFH dan masih banyak lagi kegiatan lainnya.

Secara tidak langsung mengharuskan masyarakat melakukan semua kegiatannya secara online. Termasuk kegiatan jual beli banyak dilakukan secara online sehingga daya beli masyarakat lebih banyak ke sektor informal online dibandingkan dnegan sektor informal offline. Hal ini dapat dilihat dari hasil wawancara yang telah dilakukan dilapangan.

Jika dilihat pada kondisi pandemi covid19 saat ini pelaku usaha sektor informal menjadi sorotan, karena semua kalangan terkena dampak dari pandemi covid-19 terutama pelaku usaha sektor informal. Pelaku usha sektor informal mau tidak mau harus tetap melaksanakan kegiatannya di luar rumah meski adanya aturan dari pemerintah mengenai social distancing. Kondisi ini yang menyebabkan pelaku usaha sektor informal menjalankan usahanya dengan cara offline dan online.

Kegiatan secara online dinilai dapat membantu pelaku usaha sektor informal dalam menjalankan usaha dan membantu masyarakat dalam pemenuhan kebutuhan sehari-hari dengan tidak melanggar peraturan pemerintah. Usaha secara online secara tidak langsung membantu pemerintah dalam menerapkan peraturan untuk tidak keluar rumah jika tidak diperlukan dan kontak langsung dengan masyarakat yang berpotensi meningkatkan penyebaran covid-19 (Kaur \& Kaur, 2020). Pelaku usaha sektor informal secara online menjadi hal utama yang dijalankan pada kondisi ini, selain menaati peraturan pemerintah untuk tidak berkerumun, keluar rumah jika tidak mendesak akan tetapi kondisi ini juga dinilai dapat meningkatkan kemampuan masyarakat dalam kemajuan teknologi.

Tugas besar para pelaku usaha sektor informal adalah harus mampu mengikuti perkembangan zaman dan menyesuaikan kondisi yang ada setiap saatnya. Usaha di sektor informal terbilang sangat fleksibel sehingga semua kalangan dapat masuk di sektor informal, akan tetapi kunci utama untuk tetap survive dalam menjalankan usaha di sektor informal harus mampu bersaing dengan kemajuan teknologi. Salah satu cara yang harus dilakukan pekerja sektor informal yaitu dengan melakukan transformasi usaha secara online (Hardilawati, 2020), sehingga tidak jarang pelaku usaha sektor informal yang tidak mampu mengikuti perkembang zaman akan sulit untuk berkembang dan bahkan akan tersaingi oleh sektor informal lainnya.

\section{Pendapatan Usaha Sektor Informal Offline dan Online}

Untuk menunjang pemenuhan kebutuhan hidup sehari-hari terutama bagi pekerja sektor informal adalah kebebasan dalam menjalankan usaha. Pemenuhan kebutuhan sehari-hari harus tetap berjalan dalam kondisi dan keadaan apapun, termasuk di tengah pandemi covid-19 saat ini. Pandemi Covid-19 merupakan salah satu bencana yang sifatnya insania memiliki dampak yang luar biasa dan menghambat berbagai bidang kehidupan. Seperti halnya sektor ekonomi terutama sektor informal yang merupakan sumber ekonomi utama bagi masyarakat kecil. Dengan adanya peraturan pemerintah yang berkaitan dengan pembatasan sosial berskala besar atau social distancing di masa pandemi tentunya membatasi gerak masyarakat. Hal ini tentunya akan berpengaruh pada pendapatan masyarakat itu sendiri.

Tabel 1. Pendapatan

\begin{tabular}{|l|c|c|}
\hline \multirow{2}{*}{ Usaha } & \multicolumn{2}{|c|}{ Pendapatan Sektor Informal } \\
\cline { 2 - 3 } & $\begin{array}{c}\text { Sebelum covid } \\
19\end{array}$ & Covid 19 \\
\hline $\begin{array}{l}\text { Pangkas } \\
\text { rambut }\end{array}$ & $2,5 \mathrm{jt} / \mathrm{hari}$ & $1 \mathrm{jt} / \mathrm{hari}$ \\
\hline Pedagang & $1 \mathrm{jt} / \mathrm{hari}$ & $500 \mathrm{ribu} / \mathrm{hari}$ \\
\hline Pedagang & $4 \mathrm{jt} / \mathrm{bulan}$ & $3 \mathrm{juta} / \mathrm{bulan}$ \\
\hline Pedagang & $30 \mathrm{ribu} / \mathrm{hari}$ & $\begin{array}{c}10-15 \\
\text { ribu/hari }\end{array}$ \\
\hline Pedagang & 1 juta/hari & $500 \mathrm{ribu} / \mathrm{hari}$ \\
\hline Pedagang & $150 \mathrm{ribu} / \mathrm{hari}$ & $\begin{array}{c}50-100 \\
\text { ribu/hari }\end{array}$ \\
\hline Pedagang & $100 \mathrm{ribu} / \mathrm{hari}$ & $30 \mathrm{ribu} / \mathrm{hari}$ \\
\hline $\begin{array}{l}\text { Pangkas } \\
\text { rambut }\end{array}$ & $140 / \mathrm{hari}$ & $60 \mathrm{ribu} / \mathrm{hari}$ \\
\hline Rumah makan & $800 \mathrm{ribu} / \mathrm{hari}$ & $300 \mathrm{ribu} / \mathrm{hari}$ \\
\hline $\begin{array}{l}\text { Penjual } \\
\text { gorengan }\end{array}$ & $1,2 \mathrm{juta} / \mathrm{hari}$ & $500 \mathrm{ribu} / \mathrm{hari}$ \\
\hline Bengkel motor & $300 \mathrm{ribu} / \mathrm{hari}$ & $150 \mathrm{ribu} / \mathrm{hari}$ \\
\hline Pece lele & 3 juta/hari & 1 juta/hari \\
\hline
\end{tabular}

Sumber: Data Olahan 2021

Kondisi tersebut membuat pekerja sektor informal harus mengambil langkah baru sesuai dengan kemampuan keadaan yang ada sekarang. Seperti halnya melakukan pekerjaan yang semula dilakukan secara offline untuk kondisi saat dilakukan secara online. Menurut (Hardilawati, 2020) usaha yang dilakukan 
secara online. Kondisi ini tentunya dilakukan agar kondisi pendapatan masyarakat pekerja sektor informal tetap membaik seperti waktu sebelum adanya pandemi covid-19 seperti saat ini. Seperti halnya dikatakan dalam wawancara di lapangan.

"sebelum covid melanda tempat pangkas rambut saya rama pengunjung karena pengunjungnya banyak anak usia sekolah, tapi saat ini anak-anak belajar dirumah bukan disekolah sehingga tidak rutin melakukan pangkas rambut jadi penghasilan saya menurun sampai 50 persen(1_01-Az).

Pendapatan pekerja sektor informal yaitu pemilik usaha pangkas rambut sebelum terjadinya pandemi covid-19 dalam sehari mencapai 2,5 jt/harinya. Berbeda dikondisi pandemi pendapatan mengalami penurunan sebayak 50 persen yaitu sebanyak 1 juta dalam sehari. Hal yang sama juga terjadi pada pekerja sektor informal lainnya dengan profesi sebagai pedagang makanan. Sebelum pandemi covid19 pendapatan dalam sehari bisa mencapai 1 juta rupiah, berbeda halnya di kondisi pandemi covid-19 pedapatan mengalami penurunan sebanyak 50 persen yaitu sebanyak 500.000 dalam sehari.

Dengan kondisi ini pekerja sektor informal sangat merasakan dampak dari adanya pandemi covid-19 yang terjadi saat ini, tidak hanya pedangang makanan bahkan usaha pangkas rambut dan usaha-usaha lainnya juga sangat terdampak. Kondisi ini tentunya mempengaruhi jumlah pendapatan masyarakat terutama masyarakat yang hanya fokus pada sektor informal. Terlebih masih banyaknya masyarakat yang tidak mampu mengikuti perkembangan zaman, sehingga tidak sedikit masyarakat tetap fokus pada usaha offline karena keterbatasan yang ada. Namun dalam keadaan tersebut, sebagian besar dari masyarakat tidak hanya berdiam diri meratapi keadaan yang ada. Sebagian besar masyarakat mengandalkan teknologi untuk tetap menjalankan usahanya, sehingga dari usaha sektor informal offline menjadi sektor informal online.

Kondisi pandemi covid-19 seperti saat ini, pendapatan pekerja sektor informal offline dan online tentu dapat terlihat dengan jelas perbedaannya seperti hasil wawancara yang dilakukan bahwa pemasaran yang dilakukan secara online dapat meningkatkan pendapatan sebesar 40 persen jika dibandingkan dengan penjualan atau pemasaran hanya dilakukan dengan cara ofline. Hal yang sama juga dirasakan oleh pekerja sektor informal lainnya mengatakan dengan adanya teknologi sangat membantu dalam pemasaran secara online pendapatan yang dihasilkan juga cukup membantu kebutuhan sehari-hari. Sehingga jika dilihat pada kondisi pandemi covid-19 saat ini pemasaran secara online merupakan salah satu cara yang dapat digunakan oleh pekerja sektor informal terutama para pedagang untuk mengembalikan pendapatan. Meskipun pendapatan yang diperoleh tidak sebanyak pedapatan sebelum terjadinya pandemi covid-19.

\section{Kemampuan Menabung}

Dampak adanya covid-19 tidak hanya berpengaruh terhadap kesehatan masyarakat tetapi perlahan-lahan juga membunuh mata rantai pencarian masyarakat terutama masyarakat yang bergerak di sektor informal.

Pemberlakuan PSBB yang diterapkan oleh pemerintah guna mencegah penularan covid-19 terus dilakukan hingga saat ini, seperti tidak berkerumun, menggunakan masker, mencuci tangan sampai dengan larangan berinteraksi secara dekat dengan orang lain. Kondisi ini tentunya berpengaruh besar terhadap pelaku usaha sektor informal, berkurangnya pendapatan yang diperoleh berdampak pada kemampuan menabung pelaku usaha sektor informal. Sebagian besar pelaku usaha sektor informal tidak hanya ber diam diri meratapi pandemi covid-19 saat ini, pelaku usaha sektor informal melakukan suatu cara agar usaha yang dilakukan tetap berjalan meski di kondisi pandemi saat ini, seperti beralih dari sektor informal offline menjadi sektor informal online. Seperti hasil wawancara dengan seorang pedagang makanan offline beralih menjadi pedagang makanan offline dan online.

"usaha yang saya jalankan cukup berdampak semenjak adanya covid-19, saya tidak bisa menabung seperti biasanya akan tetapi selalu saya usaha 
untuk menabung meskipun hanya sedikit" (1_03-Ep).

Selama pandemi covid-19 usaha yang dilakukan cukup terkena dampaknya yang berpengaruh pada kemampuan dalam menabung. Kegiatan menabung selalu dilakukan dan merupakan hal wajib yang harus dilakukan, akan tetapi di kondisi pandemi covid-19 seperti saat ini mengurangi jumlah tabungan yang biasa dilakukan setiap bulannya. Sebelum pandemi kemampuan menabung dalam sebulannya bisa mencapai Rp. 1.000.000/bulannya, akan tetapi untuk saat ini kemampuan menabung tetap dilakukan hanya saja dengan jumlah yang lebih sedikit yaitu berkisar 1 juta rupiah bahkan kurang.

Tidak hanya pedagang makanan akan tetapi usaha pangkas rambut di kondisi pandemi covid-19 seperti saat ini juga terkena dampaknya, berikut kutipan wawancaranya.

"Kegiatan usaha pangkas rambut yang dilakukan cukup ramai sebelum adanya pandemi covid-19, akan tetapi setelah adanya covid-19 usaha pangkas rambut yang digeluti selama ini mengalami penurunan pengunjung dan pendapatan" (1_01-Az).

Pelaku usaha melakukan pemasaran tidak hanya secara offline akan tetapi juga melakukan secara online dengan memberikan pemahaman kepada masyarakat bahwasannya usaha yang dilakukan mengikuti protokol kesehatan yang ada. Meskipun usaha pemasaran dilakukan secara offline dan online, pendapatan yang diperoleh tidak sebanyak sebelum adanya pandemi covid-19, yang berakibat pada kemampuan menabung yang rutin dilakukan setiap bulannya. Sebelum pandemi covid-19 kemampuan menabung dalam sebulan mencapai 700.000 , akan tetapi di kondisi pandemi saat ini kemampuan menabung masih tetap dapat dilakukan hanya saja jumlahnya mengalami penurunan kurang lebih 70 persen yaitu sekitar 200.000 setiap bulannya. Bahkan ada beberapa pelaku usaha sektor informal yang tidak mampu menyimpan uang setiap bulannya.

Seperti hasil wawancara yang dilakukan dengan 1_02-Da, sebagai pedagang sebelum atau setelah adanya pandemi covid-19 kemampuan untuk menabung sangat rendah bahkan tidak dapat menyimpan uang setiap bulannya. Pendapatan mengalami penurunan di masa pandemi covid-19, semula berpendapatan Rp. 1.000.000/ harinya akan tetapi dengan adanya pandemi pendapatan mengalami penurunan menjadi 500.000 perharinya. Kondisi ini berpengaruh pada kemampuan menabung pelaku usaha. Seperti diketahui bahwa tupoksi pendapatan dari pelaku usaha baik setiap harinya maupun diakumulasikan setiap bulannya yaitu untuk modal usaha, pemenuhan kebutuhan keluarga, pendidikan dan masih banyak lagi lainnya.

Tinggi kebutuhan keluarga mengharuskan pelaku usaha sektor informal bersaing di kondisi pandemi covid-19 saat ini dengan cara melakukan usaha tidak hanya secara offline akan tetapi juga dengan cara online. Kemampuan masyarakat menggunakan teknologi tentu berpengaruh besar terhadap kemampuan bersaing dalam dunia usaha di kondisi pandemi covid-19. Adanya gebrakan usaha secara online menyebabkan terbantunya pendapatan ekonomi di kala pandemi covid19. Sebagian besar masyarakat lebih memilih berbelanja secara online, selain praktis juga mengikuti anjuran pemerintah tidak keluar rumah jika tidak penting. Keadaan ini tentu berpengaruh besar terhadap jumlah pengunjung pelaku usaha offline yang juga berdampak pada pendapatan dan kemampuan menabung yang biasa dilakukan sebelum pandemi covid-19.

\section{SIMPULAN}

Pandemi covid-19 yang melanda seluruh negara di dunia termasuk Indonesia, tidak mengurangi peminat usaha sektor informal. Sejak awal sektor informal menjadi jalan pintas untuk masyarakat yang kesulitan mendapatkan pekerjaan. Sektor informal merupakan salah satu jenis pekerjaan yang terbilang sangat fleksibel dan juga dapat dilakukan oleh semua kalangan mulai dari berpendidikan rendah hingga pendidikan tinggi, usia muda hingga usia tua. Bahkan kegian usaha sektor informal tidak hanya bisa dilakukan secara offline akan tetapi juga bisa dilakukan secara online. Sebelum adanya pandemi covid-19 usaha sektor informal secara online sudah banyak diterapkan akan tetapi sebagian besar masyarakat lebih memilih membeli secara langsung karena 
terbilang murah dibandingkan membeli secara online. Akan tetapi di kondisi pandemi saat ini adanya peraturan pemerintah mengenai penerapan PSBB menyebabkan adanya perubahan pola pembelian konsumen, sehingga tidak sedikit masyarakat melakukan pembelian secara online, penularan secara online. Pembatasan dan peraturan pemerintah untuk tidak keluar rumah jika tidak diperlukan, kondisi ini menyebabkan masyarakat tidak berlama-lama di luar rumah dan bahkan tidak keluar rumah. Segala kegiatan masyarakat di kondisi pandemi covid-19 dilakukan secara online, sehingga pelaku usaha sektor informal harus menyesuaikan diri dan mampu mengkondisikan penjualan produk dan jasa. Meskipun pendapatan yang diperoleh tidak sebaik sebelum adanya pandemi covid-19. akan tetapi sektor informal online merupakan jalan yang harus ditempuh, untuk tetap melaksanakan usaha dan memenuhi kebutuhan keluarga, sehingga dapat dikatakan sektor informal di masa pandemi covid-19 lebih eksis dibandingkan dengan sektor informal offline. Karena banyak masyarakat melakukan penjualan secara online dan tidak offline, akan tetapi tidak jarang masyarakat juga melakukan usaha secara offline dan online untuk tetap bertahan dalam menjalankan usaha dan memenuhi kebutuhan hidup.

\section{UCAPAN TERIMAKASIH}

Terima kasih kepada Universitas PGRI Palembang yang telah mendanai penelitian ini, enumerator, dan kepada pelaku usaha sektor informal di Kota Palembang yang telah bersedia berpartisipasi dalam menjawab segala pertanyaan peneliti.

\section{DAFTAR PUSTAKA}

Armansyah, \& Mirna, T. (2018). Representasi Perempuan Pekerja Migran menurut Lakilaki di Kota Palembang. Populasi, 26(1), 2638. https://doi.org/https://doi.org/10.22146/j p.38687

Armansyah, Sukamdi, \& Pitoyo, A. J. (2019). Informal Sector-A Survival or Consolidation Livelihood Strategy: A Case Study of The Informal Sector Entrepreneurs in Palembang City, Indonesia. RJOAS, 11(95), 104-110. https://doi.org/10.18551/rjoas.2019-11.13

Armansyah, \& Taufik, M. (2020). Strategi Pelaku Usaha Informal Offline dan Online
Menghadapi Pandemi Covid-19 di Kota Palembang. PUBLIKAUMA: Jurnal Ilmu Administrasi Publik UMA, 8(1), 137-145. https://doi.org/10.31289/publika.v8i2.4484

BPS. (2019). Booklet Agustus 2019 Survei Angkatan Kerja Nasional. In BPS RI. Retrieved from https://www.bps.go.id/publication/downlo ad.html?

Chana, T., \& Morrison, H. (1975). Nairobi ' s informal economic sector. Ekistics, 40(237), 120-130. Retrieved from https://www.jstor.org/stable/pdf/4361855 1.pdf

Creswell, J. W. (2016). Research Design Pendekatan Metode Kualitatif, Kuantitatif, dan Campuran (4th ed.). Yoyakarta: Pustaka Pelajar.

Hardilawati, W. laura. (2020). Strategi Bertahan UMKM di Tengah Pandemi Covid-19. Jurnal Akuntansi Dan Ekonomika, 10(1), 89-98. https://doi.org/10.37859/jae.v10i1.1934

Hart, K. (1973). Informal Income Opportunities and Urban Employment in Ghana. Source: The Journal of Modern African Studies, 11(1), 61-89. Retrieved from http://www.jstor.org/stable/159873

Hart, K. (1985). The Informal Economy. The Cambridge Journal of Anthropology, 10(2), 54-58.

Kakimoto, K., Kamiya, H., Yamagishi, T., Matsui, T., Suzuki, ; Motoi, \& Wakita, T. (2020). Initial Investigation of Transmission of COVID-19 Among Crew Members During Quarantine of a Cruise Ship-Yokohama, Japan, February 2020. Morbidity and Mortality Weekly Report, 69(12), 312-313. https://doi.org/10.1016/S14733099(08)70186-5

Kaur, G., \& Kaur, C. (2020). COVID-19 and the Rise of the New Experience Economy. FIIB Business Review, 1-10. https://doi.org/10.1177/231971452095857 5

Lupia, T., Scabini, S., Mornese Pinna, S., Di Perri, G., De Rosa, F. G., \& Corcione, S. (2020). 2019 novel coronavirus (2019-nCoV) outbreak: A new challenge. Journal of Global Antimicrobial Resistance, 21, 22-27. https://doi.org/10.1016/J.JGAR.2020.02.021

Moriarty, L. F., Plucinski, M. M., Marston, B. J., Kurbatova, E. V, Knust, B., Murray, E. L., ... Friedman, C. R. (2020). Public Health Responses to COVID-19 Outbreaks on Cruise Ships - Worldwide, February-March 2020. Morbidity and Mortality Weekly Report, 69(12), 347-352. Retrieved from https://wwwnc.cdc.gov/travel/notices/war ning/novel-coronavirus-china. 
Mussurov, A., \& Rezaar Absheibani, G. (2015). Informal self-employment in Kazakhstan. IZA Journal of Labor and Development, 4(1), 9. https://doi.org/10.1186/s40175-0150031-9

Norwood, H. C. (1975). Informal Industry in Developing Countries. The Town Planning Review, 46(1), 83-94. Retrieved from https://www.jstor.org/stable/40103083

Pitoyo, A. J. (1999). Pedagang Kaki Lima pada Masa Krisis. Populasi, 10(2), 73-97. Retrieved from

https://jurnal.ugm.ac.id/populasi/article/vi ew/12485/9037

Pitoyo, A. J. (2007). Dinamika Sektor Informal di Indonesia Prospek, Perkembangan, dan Kedudukannya. Jurnal Populasi, 18(2), 129146.

Rogerson, C. M. (2017). Policy responses to informality in urban Africa: the example of Maputo, Mozambique. GeoJournal, 82, 11791194. https://doi.org/10.1007/s10708-0169735-x

Sinclair, S. W. (1976). The "Intermediate" Sector in the Economy. Manpower and Unemployment Research, 9(2), 55-59. Retrieved from https://www.jstor.org/stable/43390991

Soebyakto, B. B., \& Armansyah. (2016). Migrant Women Working at Informal Sectors : Empirical Study in Kuto Batu Village, Ilir Timur Ii Palembang City. International Journal of Humanities and Social Science, 6(4), 125-137.

Sugiyono. (2016). Metode Penelitian Kombinasi (Mixed Methods) (8th ed.; E. Sutopo, ed.). Bandung: Alfabeta.

Taufik, M., Monanisa, Nengyanti, Soebyakto, B. B., \& Armansyah. (2019). Kontribusi Perempuan Pekerja dalam Keluarga di Perkotaan. EcoBuild Journal: Economy Bring Ultimate Information All About Development Journal, 3(2), 30-39. Retrieved from http://jurnal.stiemtanjungredeb.ac.id/index. php/ecobuild/article/view/395

Timofeyev, Y. (2012). The Effects of the Informal Sector on Income of the Poor in Russia. Soc Indic Res, 111, 855-866. https://doi.org/10.1007/s11205-012-00375

Vellingiri, B., Jayaramayya, K., Iyer, M., Narayanasamy, A., Govindasamy, V., Giridharan, B., ... Subramaniam, M. D. (2020). COVID-19: A promising cure for the global panic. Science of The Total Environment, 138277. https://doi.org/10.1016/J.SCITOTENV.2020. 138277

Werlin, H. H. (1974). The Informal Sector: The Implications of the Ilo ' s Study of Kenya.
African Studies Review, 17(1), 205-212. Retrieved from https://www.jstor.org/stable/523586

Williams, C. C., \& Nadin, S. (2012). Work beyond employment: representations of informal economic activities. Work, Employment and Society, (E-special issue), 1-10. https://doi.org/10.1177/095001701243700 6

Wulantari, R. A., \& Armansyah, A. (2018). Analisis Dampak Kakarakteristik Demografi pada Perolehan Pendapatan Pekerja Perempuan Sektor Informal di Kota Palembang. The Journal of Society \& Media, 2(1), 37-52. Retrieved from https://journal.unesa.ac.id/index.php/jsm/a rticle/view/2328/pdf_1 